\title{
RAINFALL VARIABILITY AND EROSIVITY IN SEMI-ARID REGIONS: CASE OF THE WESTERN ALGERIAN REGION
}

\author{
BOUDERBALA, Djazia - nourhane_hyd@hotmail.fr \\ University of Mustapha Stambouli of Mascara / Argélia
}

SOUIDI, Zahira - souidi.z@gmail.com

University of Mustapha Stambouli of Mascara / Argélia

\author{
KATTAR, Salim - kattar.salim@gmail.com \\ Lebanese University / Libano
}

LOURENÇO, Luciano - luciano@uc.pt

Universidade de Coimbra / Portugal

NUNES, Adélia - adelia.nunes@ci.uc.pt
Universidade de Coimbra / Portugal

\begin{abstract}
This study analyzes some rainfall-related indexes in the Macta basin in northwestern Algeria, in the Orano-Mediterranean region, such as the Precipitation Index, Precipitation Concentration Index and Modified Fournier Index. Multi-factorial statistical tests were used to assess relationships between different geographic variables and precipitation parameters, based on the acquisition of monthly rainfall series from 42 stations in the catchment area, and that over 41 years. The objective of this article is to study the influence of rainfall parameters on rain erosivity in a semi-arid region (western Algeria) based on monthly rainfall series from different sites covering Macta watershed. Thus, establishing a relation between the monthly precipitaions and the energy of the rainfall intensities (EI30). The multifactorial analysis showed significant relations between the variables studied by grouping them with the same trends on the factorial axes. It was founded that the longitude-latitude- modified Fournier index group was on the same factorial axis, while the mean annual precipitation and altitude were on the other side. Altitude and latitude are the most important variables that govern the spatial distribution and variation of annual and interannual precipitation. The use of the monthly rainfall enabled to overcome the constraints of the rainfall intensities, the Precipitation-Modified Fournier Index relationship proved to be useful, showing the importance of the monthly average rainfall in the erosivity intensification.
\end{abstract}

KEYWORDS: Precipitation, erosivity, multifactorial analysis, semi-arid, western Algeria

VARIABILIDADE E EROSIVIDADE DA PRICIPITAÇÃO EM REGIÕES SEMI-ÁRIDAS: O CASO DA REGIÃO OCIDENTAL DA ARGÉLIA

RESUMO: Neste estudo analisam-se alguns índices relacionados à precipitação na bacia hidrográfica da Macta, no noroeste da Argélia, na região Orano-Mediterrânea, tais como o índice de precipitação, o índice de concentração de precipitação e o Índice Modificado de Fournier. Foram usados testes estatísticos multifatoriais para avaliar as relações entre diferentes variáveis geográficas e os índices de precipitação, com base na análise de séries mensais de 42 estações, durante 41 anos. O objetivo deste artigo é estudar a influência dos parâmetros de chuva sobre a erosividade da chuva em uma região semiárida (oeste da Argélia) a partir da aquisição de séries mensais de chuvas de diferentes locais que cobrem o solo de uma microbacia hidrográfica. Assim, é estabelecida uma relação entre as chuvas mensais e a energia das intensidades de precipitação (EI30). A análise multifatorial mostrou relações significativas entre as variáveis estudadas, agrupando-as em eixos fatoriais com as mesmas tendências. Verificou-se que o grupo longitude-latitude-índice modificado de Fournier se encontrava no mesmo eixo fatorial, enquanto a precipitação média anual e a altitude se disponham 
do outro lado. A altitude e a latitude são as variáveis mais importantes que explicam a distribuição espacial e a variação da precipitação anual e interanual. Os valores mensais permitiram superar as restrições referentes à intensidade de precipitação, a relação precipitação-índice modificada de Fournier mostrou-se útil, evidenciando a importância das precipitações médias mensais na intensificação da erosividade.

PALAVRAS-CHAVE: Precipitação, erosividade, análise multifatorial, semiárido, oeste da Argélia

\section{INTRODUCTION}

The erosivity refers to the power of precipitation to cause soil erosion. It is affected by the characteristics of precipitation such as quantity, duration, intensity, drop size, distribution and kinetic energy (CERDÀ, 1997). Soil erosion caused by precipitation is considered a main land degradation process (GRIMM et al., 2002; CERDÀ et al., 2010). The understanding of precipitation characteristics in relation with precipitation erosivity is therefore crucial to assess the soil erosion risk, and to adopt sustainable land management strategies to prevent or mitigate the soils loss. In general, there is a complex pattern of spatial and seasonal variability of rainfall in the Mediterranean region (NUNES; LOURENÇO, 2015).

Water deficit or rising temperatures have a major impact on the storage of surface and groundwater (FAYSSE et al., 2011). However, climate disturbance affects not only water availability but also changes in river regimes (NUNES and LOURENÇO, 2015), so they can have a strong influence on the productivity of ecosystems by aggravating soil erosion (PAREDES et al., 2006). Indeed, soil erosion caused by precipitation is the main land degradation process in the Mediterranean basin (CERDA et al., 2010; NUNES; LOURENÇO, 2015; NUNES et al., 2016).

According to Eltaif et al. (2010), the peculiarity of arid and semi-arid areas is that erosion is largely a result of infrequent but heavy rainfall events; therefore, rainfall erosivity data can be used as an indicator of potential erosion risks.

According to $\mathrm{Gu}$ et al. (2018), rainfall related erosivity significantly affects sediment load, in China the changes of rainfall erosivity reached 8.0 and $2.1 \%$ of sediment load during 1985-2002 and 2003-2014, respectively.

The methods of estimating the risks of erosion caused by precipitation are made from a laborious process, requiring series of continuous precipitation data over several years in the form of intensity (DE SANTOS LOUREIRO and DE AZEVEDO COUTINHO, 2001; CAPOLONGO, 2008; ANGULO-MARTÍNEZ and BEGUERÍA, 2009). These methods make it difficult to study the rainfall erosivity because obtaining these data remains an obstacle and requires heavy equipment to be mastered and qualified personnel (ANGULO-MARTÍNEZ; BEGUERÍA, 2012; DIODATO et al., 2014).

Significant relationships between annual rainfall and the Modified Fournier Index (MFI) on the one hand, and between soil erosion and annual precipitation on the other hand have been recorded by several authors (KARAMI et al., 2012; NERY, 2005; RENARD; FREIMUND, 1994; KIASSARI et al., 2012; GARCÍA-RUIZ, 2010; NUNES et al., 2010; MARTÍNEZ-CASASNOVAS et al., 2016; PRATS et al., 2013; ZIADAT TAIMEH, 2013) around the world, in Chile, 
Portugal, Italy and the Mediterranean region. Approaches are used to model rainfall erosivity and develop functions that correlate the $\mathrm{R}$-factor with more readily available (daily, monthly, annual) rainfall data (BONILLA, VIDAL, 2011; LOUREIRO AND COUTINHO, 2001, MARKER et al., 2007, DIODATO, BELLOCCHI, 2007).

In fact, very significant coefficients of correlations $(r 2=0.83$ andr2 $=0.81$ ) between MFI and the coefficient of erosivity (R) from the USLE method were obtained from 164 stations in the United States and South Africa (NUNES et al., 2016). Several researchers in Brazil also demonstrated that the MFI gave the best results in calculating the $\mathrm{R}$ factor (CASSOL et al., 2008; OLIVEIRA et al., 2011).In the semi-arid zone, Páez et al. (1983) established a relationship that estimates the erosivity of precipitation using monthly precipitation.

Arid and semi-arid regions are characterized by a lack of water and a dry climate, with precipitation being the most important limiting factor for both populations and ecosystems (KOUASSI et al., 2008). According to (NEARING et al. 2015), in semi-arid region rainfall erosivity can be expected to occur with changing climate, and because rainfall amounts being part of a function of elevation, erosivity can be expected to be influenced by elevation.

Some studies carried out in the semi-arid Maghreb have even shown the great influence of rainfall accumulations on the erosive process, whereas rain energy can be considered as a secondary cause of erosion where watersheds have steep slopes (KOURI et al., 1997, NAIMI et al., 2002). Algeria was the victim of a severe drought with an amplitude and persistence of rainfall deficit in the late 1970s. The reduction in rainfall has exceeded $36 \%$ in the country especially in its extreme west (MEDDI et al., 2009). The phenomenon of water erosion favoring soil instability has reduced the water storage capacity of dams such as the Fergoug dam in the western region downstream of our study area. The dam experienced a sharp decline in the storage capacity of dams, about $97 \%$ during the last four decades, now completely silted up. Understanding rainfall variability is critical in assessing erosion risks, allowing for a better understanding of the erosion-precipitation relationship in order to adopt sustainable land management strategies to minimize soil losses.

The objective of this article is to study the influence of rainfall parameters on rain erosivity in a semi-arid region (western Algeria) based on the acquisition of monthly rainfall series from different sites covering the soil of a watershed. Thus, establish a relation between the monthly rains and the energy of the rainfall intensities (EI30).

The study will focus on the relationships between certain geographic variables (such as latitude, longitude and altitude), climatic variables (rainfall indices) and erosivity. A multifactorial statistical analysis enabled us to assess the significant relation between the different variables.

\section{MATERIALS AND METHODS}

\subsection{STUDY ZONE}

The study area is the Macta watershed as shown in Figure 1 . The area is threatened by water erosion that resulted in silting of the reservoirs at cascade: Ouizert, Bouhanifia and Fergoug (GLIZ et al., 2015). Located in the north-west 
of Algeria the watershed covers an area of $14,390 \mathrm{~km} 2$ under a semi-arid climate. The average annual rainfall is about $321 \mathrm{~mm}$. Grain and vegetable crops dominate the southern part of the basin. These cultures cover the soil seasonally and leave it the rest of the year. To the North, forest cover was deteriorated by the anthropogenic activities, the over exploitation of soils, and by the permanent clearing and intensive overgrazing. Faced with this situation, the erosion found its scope of development due to the lack of protective vegetation, low resistance of the land and their slopes. Water from the different dams was intended to irrigate farmland in the plains of the watershed however; this water is loaded with suspended solids, which resulted in adverse effects on soils, crop yields and environment (GLIZ et al., 2015).

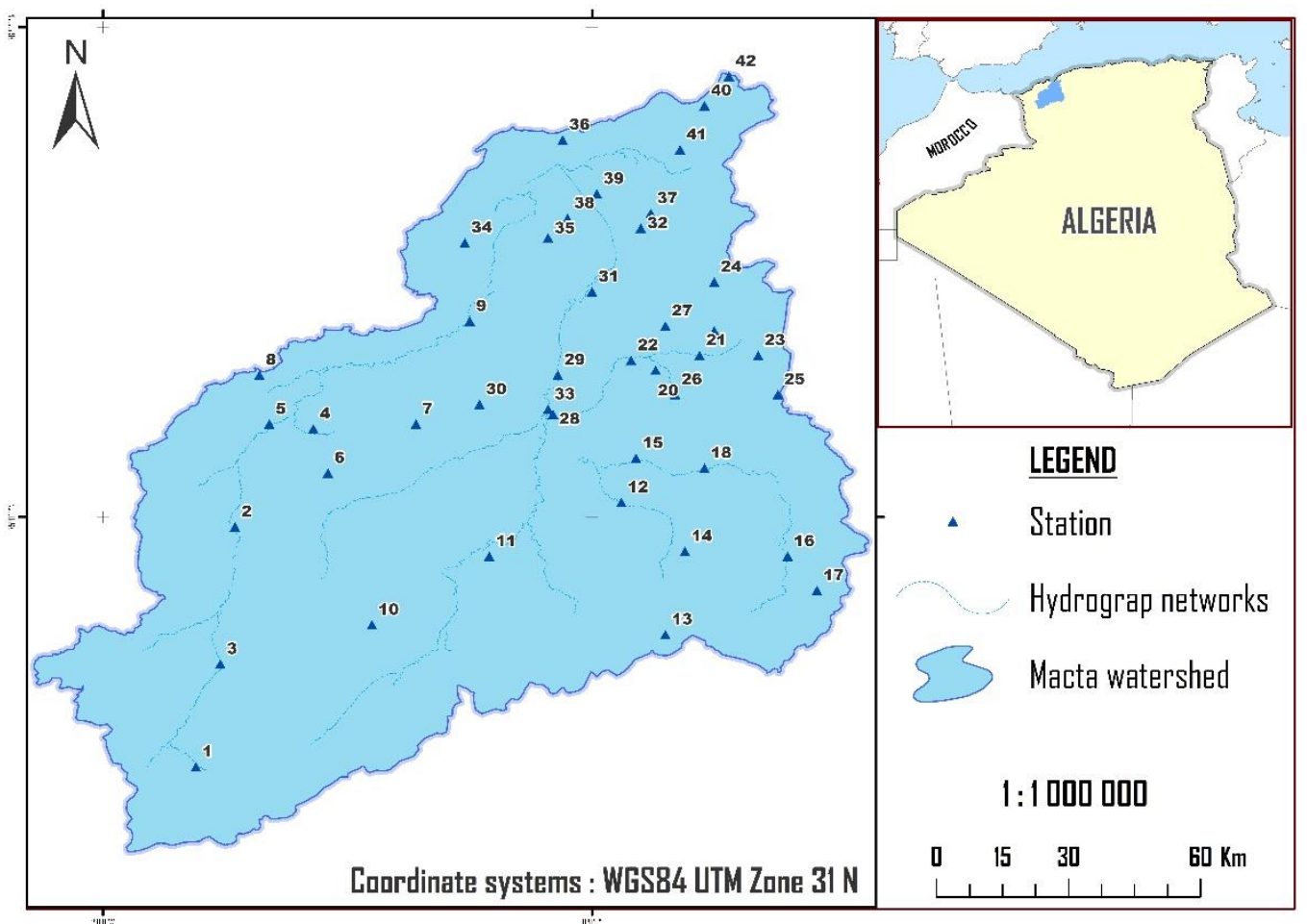

Figure 1 -Map showing the location of Macta watershed.

\subsection{DATA ANALYSIS}

The rainfall indexes (Ip), concentration index of annual mean rainfall (PCI) and modified Fournier index (MFI) were estimated for each station for the period (1970-2011). Rainfall data from the study period (1970-2011) are considered to be the most complete, they have been treated and completed at the level of the national water resources agency (BESSAKLIA et al., 2018). This data was collected by the National Agency of Hydraulic Resources (French, National Agency for Hydric Resources - ANRH). Thus, a comparison between the EI30 rainfall erosivity factor calculated by the method of Paez et al. (1983) based on monthly rainfall and the constructed MFI.

The variability of the PCI, MFI and EI30 (PAEZ et al., 2013) factors across the watershed can be described by a semi-variogram model, which is a plot of the structure function that describes the degree of linear association between pairs of values separated by a given distance (NIELSEN and WENDROTH, 2003). 
Semi-variograms allow the interpolation of values at unmeasured points in the catchment study (LI and HEAP, 2011).

A geostatistical analysis is used here by means of a linear model, which provides the best estimate of the goodness of fit index (DRAPER and SMITH, 1998). The goodness of fit of the model was evaluated by cross validation and its results were satisfactory, because the mean error was close to zero and mean squared standardized error was close to 1 .

\subsubsection{RAINFALL INDEX (IP)}

In order to assess the evolution of rainfall over the years, the rainfall index method was applied. This method was widely tested in Africa for having the advantage of highlighting the surplus and deficit periods (ELLOUZE et al., 2009; NOUACEUR et al., 2013; ZAMRANE et al., 2016). Thus, for each of the selected rainfall stations, an interannual rain index was determined (BEKKOUSSA et al., 2008), according to the following equation:

$\mathrm{I}_{\mathrm{P}}=\frac{\mathrm{X}_{\mathrm{i}}-\overline{\mathrm{X}}}{\mathrm{S}}$

With:

$\mathrm{X}_{\mathrm{i}}$ : Annual rainfall value of year $\mathrm{i}$;

$\overline{\mathrm{X}}$ : Inter-annual mean value of rainfall over the studied period;

S : Standard deviation of rainfall over the period studied.

\subsubsection{Annual average precipitation concentration index (PCI)}

Oliver (1980) proposed the PCI precipitation concentration index, which dealt with the uniformity of precipitation. This index used by several researchers in different regions of the world (APAYDIN et al., 2006; DE LUÍS et al., 2010; ELAGIB, 2011) indicates a uniform distribution of precipitation if it is less than 10. If it is between 11 and 20 it indicates a seasonal precipitation. If PCI is greater than 20 this implies a monthly climate variability of precipitation. PCI provides information on total long-term variability in the amount of precipitation received (DE LUIS et al., 2009). It is calculated by the following formula:

$$
\mathrm{PCI}_{\text {Annual }}=\frac{\sum_{\mathrm{i}=1}^{12} \mathrm{p}_{\mathrm{i}}^{2}}{\left(\sum_{\mathrm{i}=1}^{12} \mathrm{p}_{\mathrm{i}}\right)^{2}} \times 100
$$

Where: $\mathrm{Pi}$ is the monthly precipitation of month $\mathrm{i}$.

\subsubsection{MODIFIED FOURNIER INDEX (MFI)}

MFI, Modified Fournier Index by Arnoldus (1980) is considered to be the total product of annual precipitation (Pt) and monthly precipitation concentration (PCI) (APAYDIN et al., 2006).

$$
\mathrm{MFI}=\mathrm{P}_{\mathrm{t}} \times \operatorname{PCI}(3)
$$


The erosivity of precipitation based on this relationship is more severe if the values of precipitation concentration are high, and if the values of total annual precipitation are also high. Thus, precipitation concentration can be considered as the important factor affecting the erosivity of precipitation (GONZÁLEZ, 1996).

Values of MFIs above 160 are considered to be very high. Those between 120 and 160 are high. If MFI varies between 90 and 120 it is moderate, it is considered low if it is between 60 and 90, and very low if it is less than 60 (CEC, 1992).

\subsubsection{RELATION BETWEEN EI3O AND MFI}

Was also estimated the energetic intensity of rainfall using the relationship proposed by Paez et al. (1983), who developed a model to determine EI30 in Yaritagua in Venezuela for the semi-arid zone (Western Llanos), this formula has been successfully tested in our study by Bouderbala et al. (In progress). The method of calculating erosivity described by Paez has proved effective in our area (Bouderbala et al., In progress / accepted), because it makes it possible to overcome the constraint related to the unavailability of intensity data precipitation, especially in semi-arid areas. In the form:

$$
\mathrm{R}=\mathrm{EI} 30=-8,27+0,65 \mathrm{p}(5)
$$

In which $\mathrm{p}$ is the mean monthly rainfall amount.

Then was compared the intensities EI30 (PAEZ et al., 1983) with the modified Fournier index (MFI).

The rain erosivity has not been the subject of many studies in Algeria, and in that context, we have tested several relationships developed by several authors (ARNOLDUS 1980, OLIVER 1980, LEPRUN 1981, VAL et al.,1986, OLIVEIRA JR and MEDINA 1990, MORAIS et al., 1991, KASSAM et al., 1992, RENARD and FREIMUND 1994) highlighting the relationship between the rainfall erosivity factor $\mathrm{R}$ which is based on the monthly rains, and the MFI index, and we opted for the relationship developed by PAEZ et al. (1983) which shows a better correlation with a R2 $=0.9128$

\subsubsection{PRINCIPAL COMPONENT ANALYSIS (PCA)}

Multifactorial statistical analysis was introduced in order to estimate the interactions between the different variables (results obtained) and the meteorological stations.

The Principal Components Analysis (PCA) made it possible to group together according to identical factors the samples presenting characteristics of origin or similar evolution. The interpretation of the PCA consists of determining the interactions observed on the different factors and assessing the effect of each variable.

The PCA was applied to 42 weather stations with 07 variables (longitude, latitude, altitude, average annual precipitation (1970-2011), annual PCI, MFI Supplier Index, specific degradation. 


\section{RESULTS AND DISCUSSION}

\subsection{RAINFALL VARIABILITY IN THE MACTA WATERSHED}

\subsubsection{RAINFALL INDEX (IP)}

The graph of Figure 2 shows the evolution of the average rainfall index at the Macta watershed level that recorded the extreme periods between 19711977 with a negative evolution, and between 2007 and 2011 with a positive evolution. For the period of 1977-2006 the annual deficit was around $142.57 \mathrm{~mm}$. According to Lubes et al. (1994), this index is positive for wet years and negative for dry years. Taibi et al. (2013) reported an approximately $16 \%$ drop in precipitation in the study area from the 1970 s on. The years $1980 / 1990$ were the most deficient, the drought continued until 2000/2001 with a standardized rainfall index SPI <-1.5, which justifies the evolution of the IP index in our region. These results are in agreement with the work of LABORDE (1993), which shows that the decline in rainfall in northern Algeria was observed after the 1970 s in a significant way. These results are also in agreement with the conclusions of the regional report of the United Nations on climate change in North Africa (IPCC, 2007). Such changes can have adverse consequences; the decline in precipitation will result in changes in the ecosystem, runoff, groundwater recharge, agricultural water supply and cropping calendars and the fragility of soils to erosion during the summer when vegetation cover is low (NUNES et al., 2016). This decline in precipitation is confirmed by several authors who have worked on the Mediterranean basin (PAREDES et al., 2006; DE LUIS et al., 2009; GONZALEZ-HIDALGO et al., 2010; PHILANDRAS et al., 2011; NUNES and LOURENÇO, 2015). These periods can be used as reference periods to represent drought in the study area.

\section{IP mean 1970-2011}

3

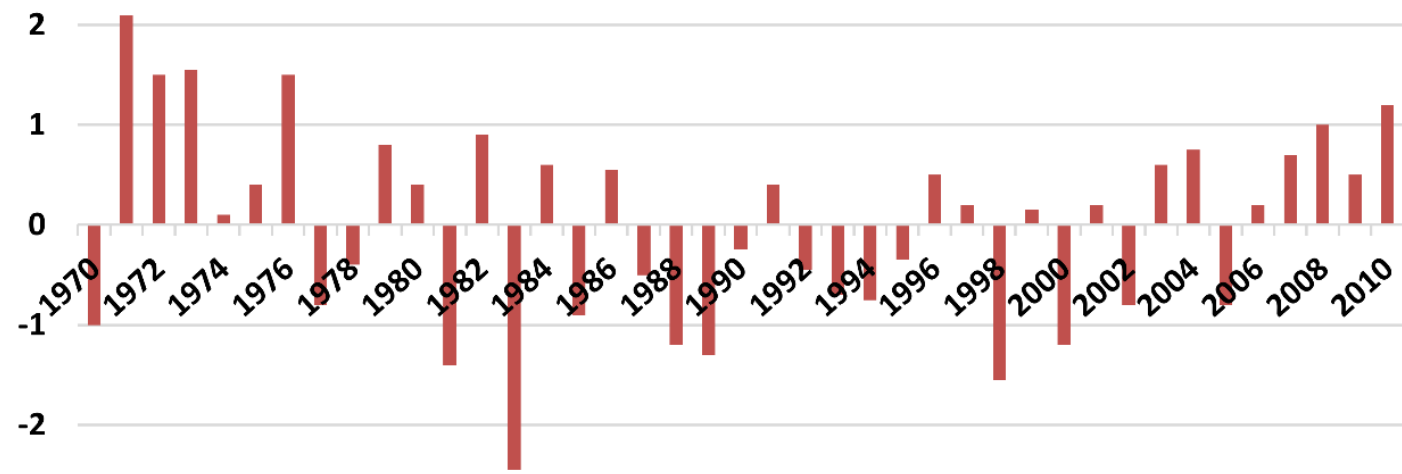

$-3$

\section{IP}

Figure 2 -Average annual rainfall index of Macta watershed (1970-2011).

\subsubsection{ANNUAL MEAN PRECIPITATION CONCENTRATION INDEX (PCI)}


PCI obtained by kriging, shows the spatial variability at the basin studied, ranging from 9.22 in the south to 12.03 in the north. The PCI values calculated for our study area are thus between 10 and 15 for the $95 \%$ of the stations present in the catchment area. This means moderate precipitation concentrations and seasonality in the precipitation distribution according to Oliver (1980) classification in agreement with (NUNES et al., 2016). Our results are in agreement with those obtained by Meddi et al. (2014) where spatial variation in PCI at annual scale showed regional variability. For the plains of Atlas of Algeria, the distribution of the PCI is moderately seasonal (less than 15).

The values obtained over the whole catchment remain low (10 to 15), but the stations located in the northern part of the basin studied near the sea (Mediterranean) represent values characterizing a tendency to irregular precipitation. Several authors have also emphasized the influence of exposure to the sea and the influence of altitude on rainfall behavior in Algeria (GHENIM and MEGNOUNIF 2013, HAMLAOUI-MOULAI et al., 2013). According to NEL and SUMNER (2006) the average rate of the increase in precipitation as a function of altitude is of the order of $5.5 \%$. According to Rodríguez-Fonseca et al. (2015), the Sahel in West Africa experienced a severe drought during the 1970s and 1980s. Most studies agree that this dry period results primarily from remote effects of sea surface temperature (SST) anomalies amplified by local land surface-atmosphere interactions. At interannual time scales, a warming of the equatorial Atlantic and Pacific/Indian Oceans results in rainfall reduction over the Sahel, while positive SST anomalies over the Mediterranean Sea tend to be associated with increased rainfall. Moreover, the discovery of the relationships between Mediterranean climate variability and WAM (the West African monsoon) dynamics motivated a new line of research in the last decade (RODRÍGUEZFONSECA et al., 2015). Rowell (2003) showed that positive SST anomalies in the Mediterranean tend to be associated with similarly positive precipitation anomalies in the Sahel. He demonstrated that increased evaporation over the positive SST anomalies leads to increased moisture content in the lower troposphere.This moistureis advected southward into the Sahel by the low-level flow across the eastern Sahara, resulting in stronger moisture convergence and precipitations.

This trend is consistent with the results of De Luis et al. (2010) in southern Spain in a Mediterranean climate. This is also consistent with the results obtained by Soares et al. (2014) confirming the influence of the distance from the coast, it showed stronger correlations with the spatial pattern of precipitation. 


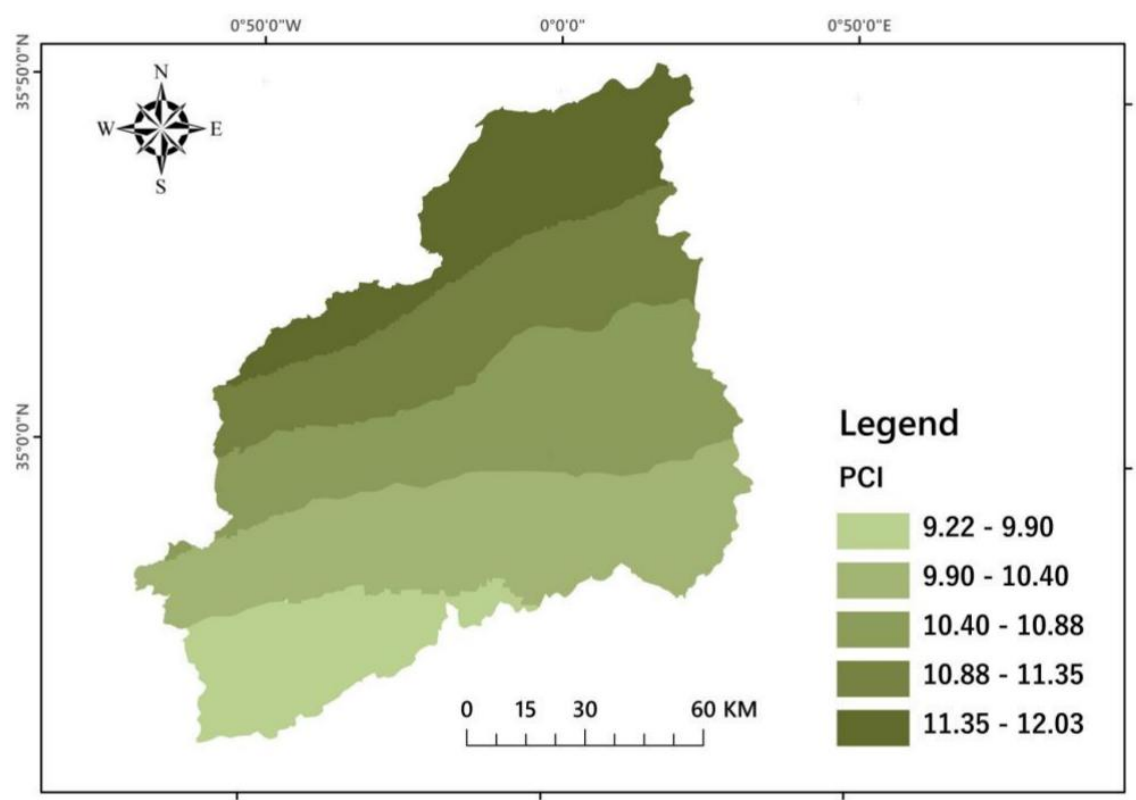

Figure 3 -Annual PCI in Macta watershed, Algeria (1970-2011).

\subsubsection{MODIFIED FOURNIER INDEX (MFI)}

The spatialized MFI (figure 4), obtained by kriging shows its average evolution in the Macta watershed, calculated on the basis of the average annual rainfall of the period studied for each station.

According to the selection made by the CEC (1992, in NUNES et al., 2016), which classifies the different values of the Fournier-Arnoldus precipitation erosivity index, the area studied is strongly characterized by an index MFI between 15.20 and $55.62 \mathrm{~mm}$ for all the meteorological stations studied, reflecting a low rate of erosion by precipitation.

According to Ghenim and Megnounif (2013) the rainfall deficit which is mainly felt during the wet season (winter and spring) had its impacts on the indices of concentration and rainfall aggression. Indeed, PCI and MFI are high when rainfall occurs during a very short period of the hydrological year and low when rainfall is distributed homogeneously. Thus, the average concentration between wet and dry sequences remained the same for all stations, although for particular years the rains were highly seasonal. Which is consistent with the results obtained by Meddi et al. (2014), where the reduction of the rainfall erosivity (MFI) has been exceeded $20 \%$ since the 1970 s. This decrease is more significant in western Algeria and the central and western steppe regions. This downward trend of rainfall erosivity is not due to the change in the concentration of rainfall inside the year since the PCI remains generally unchanged for different regions of the Northern Algeria but it is due to the decline in total rainfall (APAYDIN et al., 2006). 


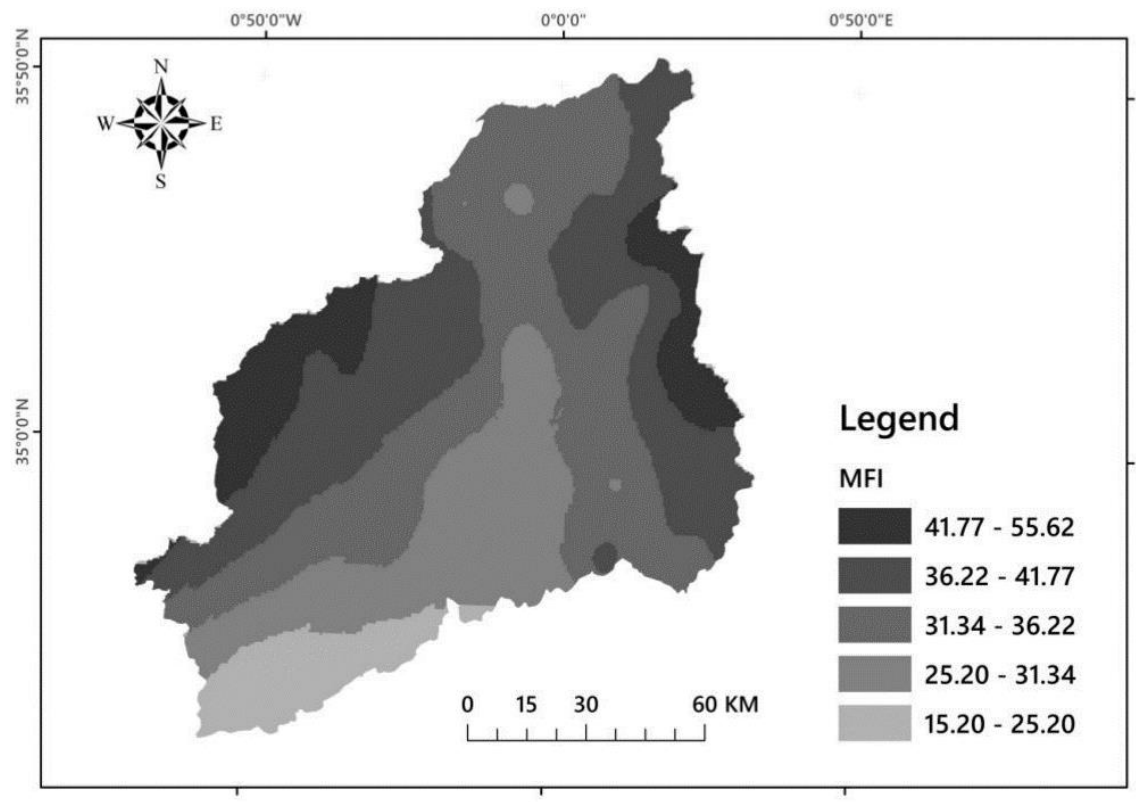

Figure 4 -MFI erosivity indices in Macta watershed, Algeria (1970-2011).

\subsubsection{RELATION BETWEEN EI30 AND MFI}

The energy intensity of rainfall estimated by the Paez et al. (1983) method shows an oscillation between 6.71 and 12.68 (Figure 5). The highest values are those corresponding to the pluviometric stations located at the extreme east of the basin $(16,17,23$ and 25) and in a part of the west (stations 4, 5 and 8) where we recorded the highest values of MFI from 36.22 to 41.77.

We also recorded the lowest values of EI30 from 6.71 to 8.0 where the values of MFI are lower 15.20 to 25.20 at station number 1 . This similarity of result was also obtained by Lujan et al. (2005) in the semi-arid region of Yaritagua in Venezuela where the relationship of Paez et al. (1983) was used. This led us to proceed with the regression between the modified Fournier index (MFI) and the rainfall intensity EI30 (Figure 6) according to Paez et al. (1983). This last gives a significant linear correlation coefficient $(R 2=0.9604)$. The regression equation is then written as follows: "EI30 $=1.6918$ MFI +103.48 " .

All points (Figure 6 ) are very close to the regression line (linear relation). This means that there is a strong link between the two indices, implying an increasing linear functional relationship. The higher the values of the MFI index, the more the rainfall intensity values rise linearly. This result should be verified in other similar regions in order to generalize the importance of the Paez et al. (1983) formula in estimating rainfall energy using monthly rainfall. 


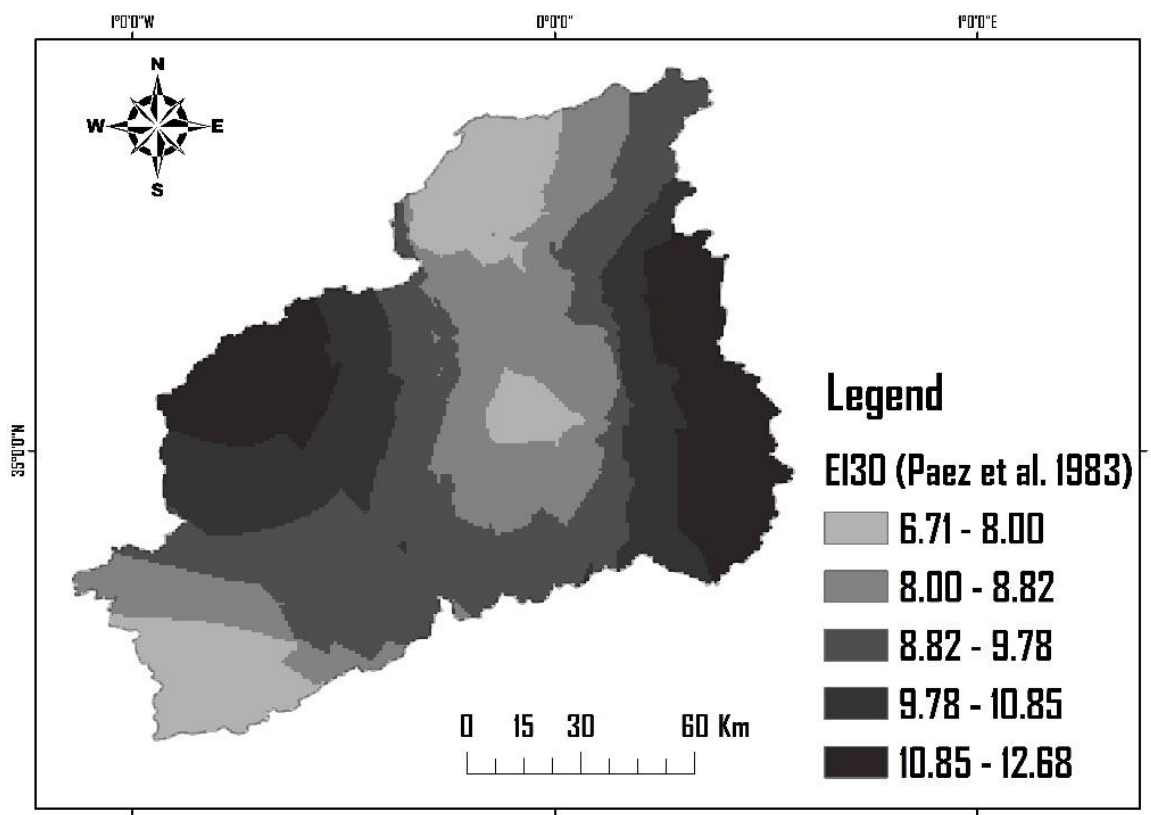

Figure 5- EI30 Paezet al. in Macta watershed, Algeria (1983)

El30 Paez et al. (1983)

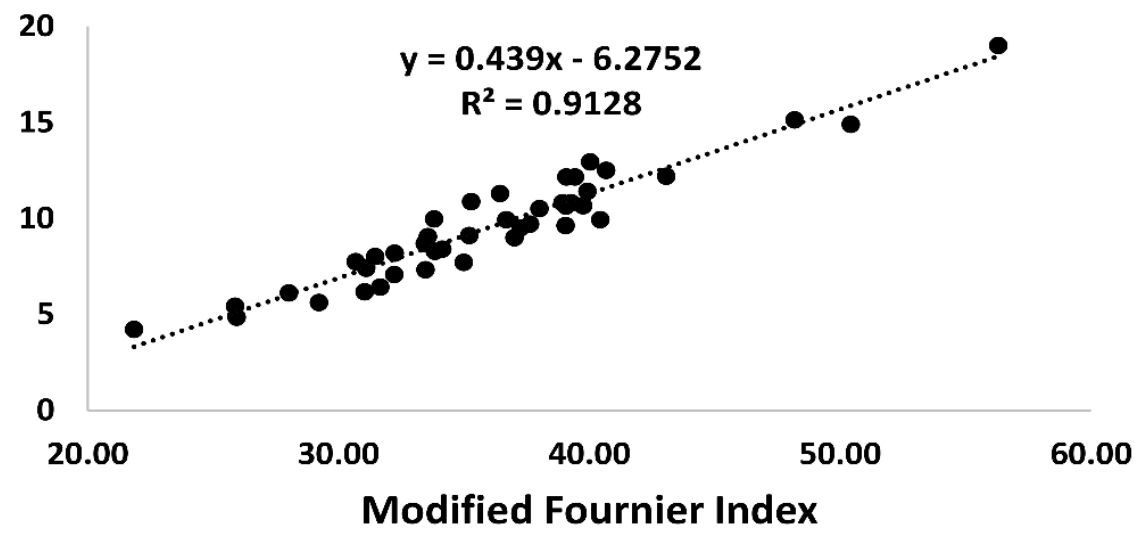

Figure 6 -Coefficient of determination between EI30 and MFI.

\subsection{DRIVING FACTORS OF EROSIVITY IN THE MACTA WATERSHED}

Six variables were integrated for standardized principal component analysis for 42 stations (stations). These variables were related with rainfall parameters (mean annual rainfall and PCI), geographic parameters (altitude, latitude and longitude) and erosivity index (MFI).

The Spearman Correlation Matrix (Table 1) makes possible to distinguish significant correlations between the variables studied. The MFI and the PCI are positively correlated. From the geographical features, altitude has the main role in the spatial distribution and variation of annual and intra-annual precipitation (DA ASSUNÇÃO BORSATO and DE SOUZA FILHO, 2010; MENDONÇA, 2005). 
Table 1 - Spearman correlation matrix between environmental variables.

\begin{tabular}{cccccc}
\hline Variables & Longitude Latitude & Altitude & $\begin{array}{c}\text { Mean Annual } \\
\text { Precipitations } \\
\mathbf{m m} \\
\mathbf{1 9 7 0 - 2 0 1 1}\end{array}$ & $\begin{array}{c}\text { PCI } \\
\mathbf{1 9 7 0}-\mathbf{1 9 7 0}\end{array}$ & $\begin{array}{c}\text { IFA } \\
\mathbf{2 0 1 1}\end{array}$ \\
\hline Longitude & 1 & & & & \\
\hline Latitude & 0.366 & 1 & & & \\
\hline Altitude & -0.107 & -0.861 & 1 & & \\
\hline $\begin{array}{c}\text { Mean Annual } \\
\text { Precipitations }\end{array}$ & 0.113 & -0.097 & 0.446 & 1 & 1 \\
\hline PCI & 0.126 & 0.881 & -0.756 & 0.092 & \\
\hline $\begin{array}{c}\text { MFI 1970- } \\
\text { 2011 }\end{array}$ & 0.101 & 0.296 & 0.047 & 0.886 & 0.516 \\
\hline
\end{tabular}

The eigenvalues represent the variance of the variables on the corresponding axis, that is, the share of the variation explained by each axis (table 2). The first three axes explained $96.98 \%$ of the total variance, with $53.44 \%$ for the first factor, $30.80 \%$ for the second and $12.73 \%$ for the third. Table 2 shows the eigenvalues of each factorial axis, the share of the variances expressed by each of these axes and their cumulation.

Table 2 -Eigenvalues for each axis.

\begin{tabular}{cccccccc} 
& F1 & F2 & F3 & F4 & F5 & F6 & F7 \\
\hline Eigenvalues & 4,276 & 2,465 & 1,019 & 0,119 & 0,075 & 0,043 & 0,004 \\
\hline $\begin{array}{c}\text { Variability } \\
\text { (\%) }\end{array}$ & 53,446 & 30,808 & 12,733 & 1,488 & 0,939 & 0,539 & 0,046 \\
\hline Cumulative & 53,446 & 84,255 & 96,988 & 98,476 & 99,415 & 99,954 & 100,000 \\
\hline
\end{tabular}

Table 3 groups the different coordinates of the different variables on the distinct axes and their correlations. It analysis makes possible to attribute to each factorial axis the most representative variables. The PCI and the Modified Fournier Index are clearly represented on the factorial axis F1. The axis F2 represents the altitude, the latitude and the mean monthly precipitation, whilst the longitude is represented by the axis F3.

Table 3 -Variable coordinates.

\begin{tabular}{cccccccc} 
& F1 & $\mathbf{F 2}$ & $\mathbf{F 3}$ & $\mathbf{F 4}$ & $\mathbf{F 5}$ & F6 & F7 \\
\hline Longitude & 0,196 & $-0,189$ & $\mathbf{0 , 9 5 9}$ & $-0,070$ & 0,004 & $-0,037$ & 0,002 \\
\hline Latitude & 0,654 & $\mathbf{0 , 7 2 3}$ & 0,119 & 0,102 & $-0,007$ & 0,158 & $-0,004$ \\
\hline Altitude & $-0,360$ & $\mathbf{0 , 9 0 0}$ & 0,139 & $-0,055$ & 0,166 & 0,099 & $-0,001$ \\
\hline $\begin{array}{c}\text { Mean annul precipitation } \\
\text { mm }\end{array}$ & 0,618 & $\mathbf{0 , 7 4 1}$ & 0,152 & 0,206 & $-0,039$ & $-0,029$ & $-0,032$ \\
\hline PCI & $\mathbf{0 , 8 1 2}$ & $-0,523$ & $-0,140$ & 0,022 & 0,206 & $-0,073$ & $-0,009$ \\
\hline MFI 1970-2011 & $\mathbf{0 , 9 0 2}$ & 0,418 & 0,010 & 0,092 & 0,002 & $-0,013$ & 0,049 \\
\hline
\end{tabular}


The analysis of the correlation circles makes possible to identify certain relations between the variables studied:

- In the $\mathrm{F} 1$ axis was defined a group of strong linked variables as show in Figure 7 and in the Figure 8, this factorial axis can be defined as rainfall erosivity indexes ;

- The F2 axis includes the Altitude and annual mean precipitation and express positive coefficients, conversely to the latitude; this axis represents the relation between rainfall and geographic variables as we can see in the Figure 7;

- The axis F3, although distinguishing the longitude variable, it has no influence on the parameters related with rainfall erosivity, as showed in Figure 8.

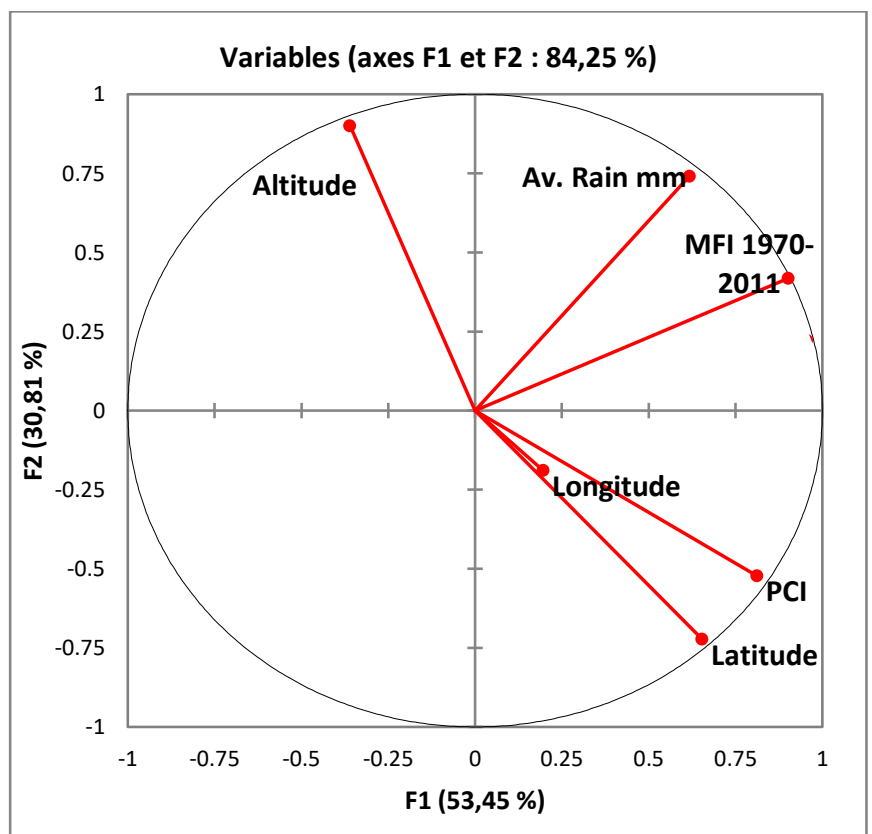

Figure 7 - Correlation circle according to plans F1 and F2. 


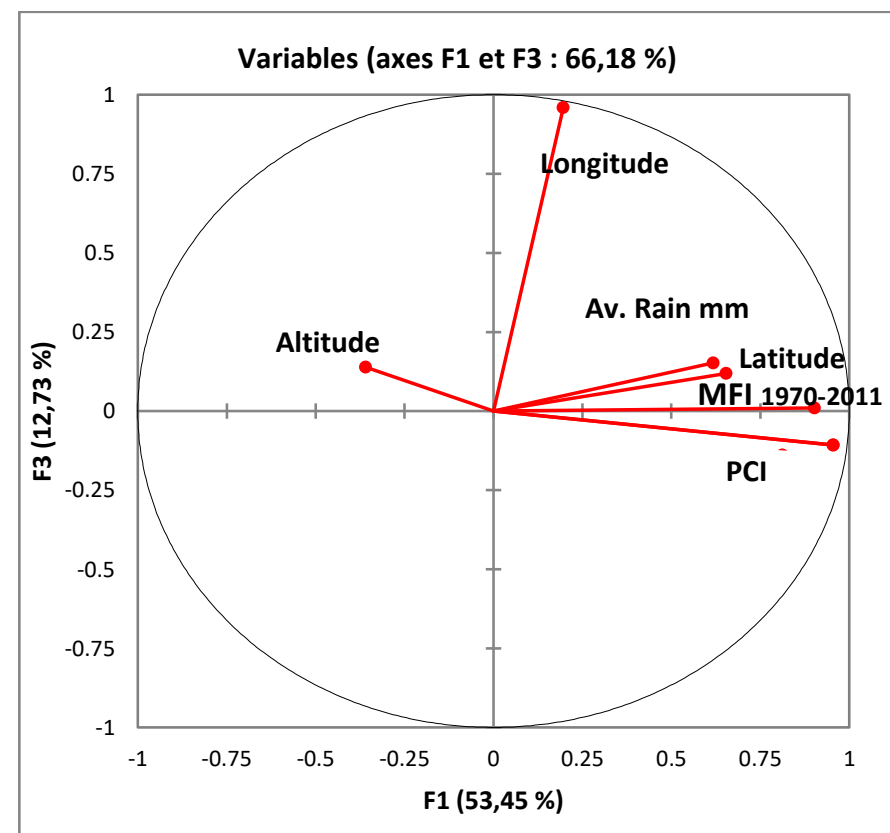

Figure 8 - Correlation circle according to plans F1 and F3.

\section{CONCLUSION}

The principal component analysis made it possible to highlight the impact of the Fournier indices and the annual precipitation concentration on the components of the rainfall erosivity.

The comparison between the energy of the erosivity index of the Paez et al. (1983) method and the MFI index shows a very high correlation, which confirms the dependence on the average monthly rains. This result can be very effective in areas prone to erosion and those suffering from the lack of information on rainfall intensity.

The results of this study are interesting and conclusive, in the way they explain the dependence of the erosion, the quality of monthly rains and the modified Fournier index based on the monthly rains in an area where erosion studies are rare, and data on rainfall intensities are hard to find. They can be very useful for a better understanding of the combination of parameters that influence soil degradation in order to better plan the protection systems of the soils and waters in prone regions.

\section{REFERENCES}

ANGULO-MARTÍNEZ, M.; BEGUERÍA, S. Estimating rainfall erosivity from daily precipitation records: A comparison among methods using data from the Ebro Basin (NE Spain). Journal of Hydrology, 379(1): 111-121, 2009.

ANGULO-MARTÍNEZ, M.; BEGUERÍA, S. Trends in rainfall erosivity in NE Spain at annual, seasonal and daily scales, 1955-2006. Hydrology and Earth System Sciences, 16(10): 3551-3559. DOI: 10.5194/hess-16-3551, 2012. 
APAYDIN, H.; ERPUL, G.; BAYRAMIN, I.; GABRIELS, D. Evaluation of indices for characterizing the distribution and concentration of precipitation: A case for the region of Southeastern Anatolia Project, Turkey. Journal of Hydrology, 328(3): 726-732. DOI : 1016/j.jhydrol.2006.01.019, 2006.

ARNOLDUS, HMJ. An approximation of the rainfall factor in the Universal Soil Loss Equation. In: Assessment of Erosion, Boodt M. \& Gabriels D. editors. John Wiley \& Sons, Chichester, 1980, 127-132.

BEKKOUSSA, B., MEDDI, M., JOURDE, H. Forçage climatique et anthropique sur la ressource en eau souterraine d'une région semi-aride: cas de la plaine de Ghriss (Nord-Ouest algérien). Science et changements planétaires/Sécheresse, 19(3), 173-184, 2008.

BERTONI, J.; LOMBARDI NETO, F. Conservação do solo. 2.ed. São Paulo, Ícone(in portuguese), 1990.

BOUDERBALA, D.; SOUIDI, Z.; LUCIANO, L.; HAMIMED, A.; BOUAMAR, B. Estimativa da erosividade da chuva por mapeamento na bacia de Macta (Argélia). Revista Braseleira de Cartografia, (accepted / in process).

BONILLA, C.A.; VIDAL, KL. Rainfall erosivity in central Chile. Journal of Hydrology, 410 (1-2): 126-133, 2011.

CAPOLONGO, D.; DIODATO, N.; MANNAERTS, C.; PICCARRETA, M.; STROBL, RO. Analyzing -temporal changes in climate erosivity using a simplified rainfall erosivity model in Basilicata (southern Italy). Journal of Hydrology, 356(1): 119130, 2008.

CASSOL, E.A.; ELTZ, F.; MARTINS, D. ; LEMOS, AM. ; LIMA, VS. ; Bueno, A.C. Erosividade, padrõeshidrológicos, período de retorno e probabilidade de ocorrênciadaschuvasem São Borja, RS. Revista Brasileira de Ciência do Solo, 32: 1239-1251, 2008.

CEC. CORINE soil erosion risk and important land resources in the southern regions of the European Community. Comission of the European Communities, Luxembourg, 1992, $97 \mathrm{pp}$.

CERDÀ, A. Rainfall drop size distribution in the Western Mediterranean basin, Valencia, Spain. Catena, 30(2-3): 169-182, 1997.

CERDÀ, A.; HOOKE, J.; ROMERO-DIAZ, A.; MONTANARELLA, L.; LAVEE, H. Soil erosion on Mediterranean Type Ecosystems Land Degradation and Development. Land DegradationandDevelopment, 21(2): 71-74, 2010.

DA ASSUNÇÃO BORSATO, V.;EDVARD ELIAS DE SOUZA, F. A participação dos sistemas atmosféricos atuantesnabacia do rio Paraná no período 1980 a 2003. Revista Brasileira de Climatologia,vol. 7, 2010.

DE LUIS, M.; GONZÁLEZ-HIDALGO, JC.; LONGARES, LA.Is rainfall erosivity increasing in the Mediterranean Iberian Peninsula. Land Degradation and Development,21(2):139-144. DOI: 10.1002/Idr.918, 2010.

DE LUIS, M.; GONZÁLEZ-HIDALGO, JC.; LONGARES, LA.; ŠTEPÁNEK, P. Seasonal precipitation trends in the Mediterranean Iberian Peninsula in second half of 20th century. InternationalJournalofClimatology, 29(9): 1312-1323.DOI: $10.1002 /$ joc. $1778,2009$. 
DE SANTOS LOUREIRO, N.; DE AZEVEDO COUTINHO, Miguel. A new procedure to estimate the RUSLE EI30 index, based on monthly rainfall data and applied to the Algarve region, Portugal. Journal of hydrology,250 (1-4), 12-18, 2001.

DIODATO, N.; BELLOCCHI, Gianni. Estimating monthly (R) USLE climate input in a Mediterranean region using limited data. Journal of Hydrology, 345 (3-4), 224236, 2007.

DIODATO, N.; VERSTRAETEN, G.; BELLOCCHI, G. Decadal modelling of rainfall erosivity in Belgium. Land degradation \& development, 25(6): 511-519.DOI: 10.1002/Idr.2168, 2014.

DE SANTOS LOUREIRO, N.; DE AZEVEDO COUTINHO, M. A new procedure to estimate the RUSLE EI 30 index, based on monthly rainfall data and applied to the Algarve region, Portugal. Journal of hydrology, 250(1): 12-18. DOI: 10.1016/S0022-1694(01)00387-0, 2001.

DRAPER, N.; Smith, H. Applied regression analysis (3rd ed.). John Wiley, ISBN: 0-471-17082-8, 1998.

ELAGIB, NA. Changing rainfall, seasonality and erosivity in the hyper arid zone of Sudan. Land degradation \& development, 22(6): 505-512.DOI: 10.1002/Idr.10232011, 2011.

ELTAIF, NI.; GHARAIBEH, MA.; AL-ZAITAWI, F. ; et al. Approximation of rainfall erosivity factors in North Jordan. Pedosphere, v.20, n.6, pp. 711-717, 2010.

ELLOUZE, M. ; Azri, C. ; Abida, H. Spatial variability of monthly and annual rainfall data over Southern Tunisia. Atmos Res, 93:832-839. https://doi.org/10.1016/j.atmosres.2009.04.005,2009.

FAYSSE, N.; HARTANI, T.; FRIJA, A.; TAZEKRIT, I.; ZAIRI, C.; CHALLOUF, A. Usage agricole des eaux souterraines et initiatives de gestion au Maghreb: défis et opportunités pour un usage durable des aquifères. Note Economique de la BAD, 1-24, 2011.

IPCC. Climate change 2007: impacts, adaptation and vulnerability Contribution of working group II to the fourth assessment report of the Intergovernmental Panel on Climate Change. Parry MLCanziani OF, Palutikof JP, van der Linden PJ and Hanson CE (eds). Cambridge University Press, Cambridge, 2007. p 976.

GARCÍA-RUIZ, JM. The effects of land uses on soil erosion in Spain: a review. Catena, 81 (1): 1-11, 2010.

GHENIM, A. N., MEGNOUNIF, A. Analyse des précipitations dans le Nord-Ouest algérien. Science et changements planétaires. Sécheresse, 24 (2), 107-114, 2013.

GLIZ, M. ; REMINI, B. ; ANTEUR, D. ; MAKHLOUF, M. Vulnerability of soils in the watershed of Wadi El Hammam to water erosion (Algeria). Journal of Water and Land Development, 24 : 3-10, 2015.

GONZÁLEZ-HIDALGO, J.C. Los índices de agresividad de la lluvia y su aplicación en la valoración de la erosión del suelo. Cuadernos Técnicos de la Sociedad Española de Geomorfología vol. 10, Geoforma Ediciones: Logroño (in Spanish), 1996. 
GONZALEZ-HIDALGO, JC.; BRUNETTI, M.; DE LUIS, M. Precipitation trends in Spanish hydrological divisions, 1946-2005. Climate Research, 43 (3): 215-228. DOI: $10.3354 / \mathrm{cr00937,} 2010$.

GRIMM, M.; JONES, R..; MONTANARELLA, L. Soil erosion risk in Europe. European Commission, Institute for Environment and Sustainability: European Soil Bureau, 2002.

GU, C., MU, X., GAO, P., ZHAO, G., SUN, W.; YU, Q. Erosivité des pluies et charge sédimentaire sur le bassin du lac Poyang sous des activités climatiques et humaines variables depuis les années 1960. Climatologie théorique et appliquée, 1-16, 2018.

HAMLAOUI-MOULAI, L. ; MESBAH, M. ; SOUAG-GAMANE, D. ; MEDJERAB, A. Detecting hydro-climatic change using spatiotemporal analysis of rainfall time series in Western Algeria. Natural Hazards, 65 : 1293-311. doi: 10.1007/s11069-0120411-2, 2013.

KARAMI, A.; HOMAEE, M.; NEYSHABOURI, MR.; AFZALINIA, S.; BASIRAT, S. Large scale evaluation of single storm and short/long term erosivity index models. Turkish Journal of Agriculture and Forestry, 36(2): 207-216. DOI: 10.3906/tar-1102-24, 2012.

KASSAM, A.H.; VELTHUIZEN, H.T.; MITCHELL, A.J.B.; FISHCHER G.W.; SHAH, M.M. Agro-Ecological Land Ressources Assessment ford Agricultural Development Planning, 1992.

KIASSARI, EM.; NIKKAMI, D.; MAHDIAN, MH.; PAZIRA, E. Investigating rainfall erosivity indices in arid and semiarid climates of Iran. Turkish Journal of Agriculture and Forestry, 36(3): 365-378. DOI:10.3906/tar-1103-9, 2012.

KOUASSI, AM.; KOUAMÉ, KF.; GOULA, BTA.; LASM, T.; PATUREL, JE.; BIÉMI, J. Influence de la variabilité climatique et de la modification de l'occupation du sol sur la relation pluie-débit à partir d'une modélisation globale du bassin versant du N'zi (Bandama) en Côte d'Ivoire. Rev Ivoir Sci Technol, 11: 207-229, 2008.

KOURI, L. ; VOGT, H. ; GOMER, D. Analyse des processus d'érosion hydrique linéaire en terrain marneux. Bassin-versant de l'oued Mina, Tell Oranais, Algérie. Bull Réseau Erosion, 17: 64-73, 1997.

LABORDE. J. Carte pluviométrique de I'Algérie du Nord à l'échelle du 1/500000, Agence Nationale des Ressources Hydrauliques, projet PNUD/ALG/88/021, une carte avec notice explicative, 1993, p 44.

LEPRUN, J.C. A erosa ̃, a conservac_a o e o manejo do solo no Nordeste Brasileiro. Recife:Ministe 'rio do Interior. SUDENE, Brasil, 1981.

LI, J. ; HEAP, AD. A review of comparative studies of spatial interpolation methods in environmental sciences: Performance and impact factors, Ecological Informatics, 6 (3-4): 228-241, 2011.

LOBO LUJAN, D.; GABRIELS, D. Assessing the raine rosivity and rain distribution in different agro-climatological zones in Venezuela. Sociedade \& Natureza, 1( 1 ), 2005.

LUBES, H. ; MASSON, J.M. ; SERVAT, E. ; PATUREL, JE. ; KOUAME, B. ; BOYER, JF. Caractérisation de Fluctuations dans une Série Chronologique par 
Applications de Tests Statistiques-Etude Bibliographique Etude bibliographique. Programme ICCARE. 1994. Rapport n³. ICCARE.ORSTOM, Montpellier, France.

MÄRKER, M.; ANGELI, L.; BOTTAI, L.; et al. Assessment of land degradation susceptibility by scenario analysis: A case study in Southern Tuscany, Italy. Geomorphology, 93 (1-2), 120-129, 2008.

MARTÍNEZ-CASASNOVAS, JA.; RAMOS, MC.; BENITES, G. Soil and Water Assessment Tool Soil Loss Simulation at the Sub-Basin Scale in the Alt PenedèsAnoia Vineyard Region (Ne Spain) in the 2000s. Land Degradation \& Development, 27(2): 160-170. DOI: 10.1002/Idr.2240, 2016.

MEDDI, M.; TALIA, A.; MARTIN, C. Évolution récente des conditions climatiques et des écoulements sur le bassin versant de la Macta (Nord-Ouest de l'Algérie). Physio-Géo. Géographie physique et environnement, (3): 61-84, 2009.

MEDDI, M., S. TOUMI, A. ASSANI.; ESLAMIAN, S. Régionalisation de l'érosivité des précipitations dans le nord de l'Algérie. Journal international des sciences et technologies de I'hydrologie, 4 (2), 155-175, 2014.

MENDONÇA, FM. Clima, tropicalidade e saúde:umaperspectiva a partir da intensificação do aquecimento global. RevistaBrasileira de Climatologia, 1(1), 2005.

MORAIS, L.F.B. ; SILVA, V. DA. ; NASCHIENVENG, T.M. DA C. ; HARDOIN, P.C. ; ALMEIDA, J. EDE. ; WEBER, O. DOS S. ; BOEL, E. ; DURIGON, V.Indice EI30 e sua relaçaocom o coeficiente de chuva do sudoeste de Mato Grosso. R. Bras. Ci. Solo, 15, 339-344 (in Portuguese), 1991.

NAIMI, M. ; TAYAA, M. ; OUZIZI, S. ; CHOUKR-ELAH, R. ; Kerby, M. Ravinement dans le bassin du Nakhla. Bull Réseau Erosion, 21: 232-43, 2002.

NEARING, M.. A. ; UNKRICH, C. L. ; GOODRICH, D. C. ; NICHOLS, M. H. ; KEEFER, T. O. Temporal and elevation trends in rainfall erosivity on a $149 \mathrm{~km} 2$ watershed in a semi-arid region of the American Southwest. International Soil and Water Conservation Research, 3 (2) : 77-85, 2015.

NEBIE, O. Degradation du milieu et amenagement dans le plateau central, Burkina Faso. Berichte des Sonder for schungsbereichs 268, Band 7, Frankfurt a. M, 1996, pp. 149-176.

NEL, W. ; SUMNER, P. Trends in rainfall total and variability (1970-2000) along the Kwazulu Natal Drakensberg foothills. SouthAfricanGeographicalJournal, 88 : 130-7, 2006.

NERY, JT. Dinâmicaclimática da regiãosul do Brasil. Revista Brasileira de Climatologia, 1(1), 2005.

NIELSEN, DR. ; WENDROTH, O. Spatial and temporal statistics: sampling field soils and their vegetation. Reiskirchen: Catena Verlag, GMBH, 2003.

NOUACEUR, Z. ; LAINGEL, B. ; TURKI, I. Changements climatiques au Maghreb: vers des conditions plus humides et plus chaudes sur le littoral algérien? GéogrPhys Environ, 7:307-323, 2013a.

NUNES, AN.; COELHO, COA.; DE ALMEIDA, AC.; FIGUEIREDO, A. Soilerosion and hydrological response to land abandonment in a central in land area of 
Portugal. Land Degradation \& Development, 21 (3): 260-273.DOI: 10.1002/Idr.973, 2010.

NUNES, AN.; LOURENÇO, L.; VIEIRA, A.; BENTO-GONÇALVES, A. Precipitation and erosivity in southern Portugal: seasonal variability and trends (1950-2008). Land Degradation \& Development, 27(2): 211-222. DOI: 10.1002/ldr.2265, 2016.

NUNES, AN.; LOURENÇO, L. Precipitation variability in Portugal from 1960 to 2011. Journal of Geographical Sciences, 25(7): 784-800. DOI: $10.1007 /$ s11442015-1202-y, 2015.

OLIVER, JE. Monthly precipitation distribution: a comparative index. The Professional Geographer, 32(3): 300-309, 1980.

OLIVEIRAJR, R.C.; Medina, B.F. A erosividadedaschuvasem Manaus (AM). Rev. Bras. Cie^nc. Solo 14 : 235-239, 1990.

OLIVEIRA, PTS. ; RODRIGUES, DBB. ; ALVES SOBRINHO, T. ; CARVALHO, DF. ; PANACHUKI, E. Spatialvariabilityoftherainfallerosivepotential in theStateof Mato Grosso do Sul, Brazil. Engenharia Agrícola, 32:69-79, 2011.

PAEZ, ML.; RODRÍGUEZ, OS.; LIZASO, J. Preliminary evaluation of Universal Soil Loss Equation factors in Venezuela. International Conference on Soil Erosion and Conservation. Mimeografiado, Honolulu, Hawaii, 1983.19 p.

PAREDES, D.; TRIGO, RM.; GARCIA-HERRERA, R.; TRIGO, IF. Understanding precipitation changes in Iberia in early spring: weather typing and stormtracking approaches. Journal of Hydrometeorology, 7 (1): 101-113, 2006.

PRATS, SA.; MALVAR, MC.; VIEIRA, DCS.; MACDONALD, L.; KEIZER, JJ. Effectiveness of hydro mulching to reduce runoff and erosion in a recently burnt pine plantation in central Portugal. Land degradation \& development, 27 (5):1319-1333.DOI: 10.1002/Idr.2236, 2013.

RENARD, KG.; FREIMUND, JR. Using monthly precipitation data to estimate the R-factor in the revised USLE. Journal of hydrology, 157 (1-4): 287-306, 1994.

RODRÍGUEZ-FONSECA, B.; MOHINO, E.; MECHOSO, CR.; et al. Variability and predictability of West African droughts: A review on the role of sea surface temperature anomalies. Journal of Climate, v.28, n.10, pp. 4034-4060, 2015.

ROWELL, DP. The impact of Mediterranean SSTs on the Sahelian rainfall season. J. Climate, v.16, 849 - 862, 2003.

SILVA, V.; PEREIRA, E.; RAFAELA, S. A study on annual and intra-annual variability of rainfall over Northeastern Brazil. Rev. bras. meteorol. v.27, n.2, pp.163-172.http://dx.doi.org/10.1590/S0102-77862012000200005, 2012.

SOARES, FS.; FRANCISCO, CN.; SENNA, MC. Spatio-temporal precipitationdistribution in Ilha Grande BayHydrographicRegion - Rio de Janeiro. Rev. bras. meteorol. , v.29, pp.125-138. http://dx.doi.org/10.1590/S0102$77862014000100012,2014$.

TAIBI, S. ; MEDDI, M. ; SOUAG, D. ; MAHE, G. Évolution et régionalisation des précipitations au nord de l'Algérie (1936-2009). Climate and land surface changes in hydrology, 359 : 191-197, 2013. 
Val, L.A.; Bahia, V.G.; Freire, J.C.; Dias Junior, M.S. Erosividadedaschuvasem Lavras, MG. Cienc. Prat., 10: 199-209, 1986.

WANDERLEY, H.; AMORIM, R.; CARVALHO, F. Spatial variability and missing precipitation data filling in Alagoas state. Rev. bras. meteorol. v.27, n.3, pp.347-354, http://dx.doi.org/10.1590/S0102-77862012000300009, 2012.

ZAMRANE, Z. ; IURKI, I. ; LAINGEL, B. ; MAHE, G. ; LAFTOUHI, N. Characterization of the interannual variability of precipitation and stream flow in Tensift and Ksob basins (Morocco) and links with the NAO. Atmosphere, (7):84. https://doi.org/10.3390/atmos 7060084, 2016

ZIADAT, FM.; TAIMEH, AY. Effect of rainfall intensity, slope, land use and antecedent soil moisture on soil erosion in an arid environment. Land Degradation \& Development, 24(6): 582-590. DOI:10.1002/Idr.2239, 2013. 